\title{
Companies and UN 2030 Sustainable Development Goal 9 Industry, Innovation and Infrastructure
} Janice Denoncourt*

Nottingham Law School, UK

\begin{abstract}
:
This article analyses the important connection between corporate longevity, social responsibility and intellectual property rights (IPR) assets in the context of sustainability. Society is demanding greater transparency of the footprint corporate entities leave on the planet as a result of how their business model is activated. The private sector response necessary to operate sustainably in the long term is critically examined specifically in connection with the United Nations 2030 Sustainable Development Goal 9 Industry, Innovation and Infrastructure (SDG 9). SDG 9 aims to "Build resilient infrastructure, promote inclusive and sustainable industrialization and foster innovation". Certain characteristics of companies in the century club are contrasted with those of the younger MNEs with IP-reliant digital business models to illustrate the important connection between innovation, IP, sustainability and corporate longevity. Learning from the management literature about the characteristics of established companies in the 'century club' together with a deeper understanding of core innovation theory may buttress the new digital MNE's adaptability, commercial success and longevity, within the wider sustainable industrialization context.
\end{abstract}

Keywords: business model; corporate governance stewardship code; corporate longevity; corporate social responsibility (CSR); digital economy; innovation; intangibles; intellectual property; IPR; sustainability; UN sustainable development goal 9; UK Intellectual Property 
Office; UKIPO; World Intellectual Property Organization; WIPO; World Trade Organization; WTO.

\section{Introduction}

To sustain the planet and its future population of 8.5 billion by $2030^{1}$ innovation and creativity will be vital to driving more efficient and better use of resources. The global task of achieving the United Nations 2030 Agenda for Sustainable Development Goals (SDGs) has the overarching societal goal of ensuring 'development that meets the needs of the present while safeguarding Earth's life-support system, on which the welfare of current and future generations depends'. ${ }^{2}$ Such development necessarily has a private sector corporate innovation and intellectual property (IP) asset dimension that appears to be missing in the sustainability literature to date. Further, as society has changed traditional manufacturing and simple supply chains have declined and are often being replaced by digital and IP-reliant business models operating in the intangible (virtual or weightless) economy. Firms with new digital technologies create new markets and value networks that impact on established markets, firms, products and alliances. ${ }^{3}$ Our creators and innovators across the globe will need to invent the future essential for achieving the UN SDG Agenda. However, not only will innovation need to be harnessed, companies will need successful and adaptable business models to be profitable in the long term, well beyond 2030, if they are to achieve corporate longevity, and the profitability needed to support CSR activities that contribute to a sustainable future. Certain enterprises may even join the select group of century club firms and achieve sustainable industrialization envisaged by SDG 9.

The research in this article examines, from an interdisciplinary perspective, the important connection between innovation and IP rights, corporate longevity and CSR, which arguably provide the foundation for the sustainable industrialization contemplated in SDG 9. The new digital business models driving the virtual economy are heavily reliant on 
innovation protected by monopolistic intellectual property rights (IPRs) such as copyright (to protect software and creative content), patents (to protect technology) and trade marks (to protect corporate and house brands). Researchers agree that intangible ${ }^{1}$ assets which include IPRs typically comprise the majority of financial corporate value. This article identifies certain characteristics of younger multinational corporations (MNEs) with IP-reliant digital business models contrasted with more established patent-reliant pharmaceutical firms to illustrate the links between innovation, IP, sustainability and corporate longevity. It identifies the need for companies to have a better understanding of core innovation theory to optimize the selection and adaptation, over time, of their core business model to maintain a level of profitability that actuates corporate social responsibility activities. In theory, a deeper understanding of core innovation theory and the characteristics of companies who have sustained for over a century or longer, may provide corporations with insights to enable them to better adapt with a view to achieving commercial success and longevity, within the wider sustainable industrialization context. The question, "In whose interests is the company run?" juxtaposed with the SDG 9 concept of 'sustainable' industrialization contemplates that companies adopt a broader pluralist approach beyond shareholder primacy. ${ }^{4}$ To provide background to the analysis, the next section introduces the UN 2030 Agenda and in particular, SDG 9 Industry, Innovation and Infrastructure.

\subsection{UN 2030 SDG 9: Innovation, IPRs and sustainable business models}

When the Heads of State and Government met in New York on 25 -27 September 2015 to celebrate the seventieth anniversary of the United Nations (UN), they decided to adopt the 2030 Agenda for Sustainable Development ${ }^{5}$ to enhance and extend the UN's Millennium Development Goals made 15 years earlier. They boldly committed to achieving sustainable

\footnotetext{
${ }^{1}$ From a corporate reporting and financial accounting perspective, the International Accounting Standard 38 Intangibles defines intangibles as intellectual assets lacking in physical presence with an uncertain future value or amount of benefit that benefit an entity over several accounting periods. See https://www.iasplus.com/en/standards/ias/ias38 accessed on 22 March 2019.
} 
development in its three dimensions: economic, social and environmental. The preamble states:

This Agenda is a plan of action for people, planet and prosperity. It also seeks to strengthen universal peace in larger freedom. We recognise that eradicating poverty in all its forms and dimensions, including extreme poverty, is the greatest global challenge and an indispensable requirement for sustainable development. All countries and all stakeholders, acting in collaborative partnership, will implement this plan. We are resolved to free the human race from the tyranny of poverty and want and to heal and secure our planet. We are determined to take the bold and transformative steps which are urgently needed to shift the world onto a sustainable and resilient path...

The new SDGs and targets came into effect on 1 January 2016 and now guide all UN decisions that will be taken until 2030. SDG 9 relates to Industry, Innovation and Infrastructure and aims to:

Build resilient infrastructure, promote inclusive and sustainable industrialization and foster innovation.

A discussion of the meaning of the term 'sustainability' in a business and industrial helps is instructive. In their article article, 'Clarifying the Meaning of Sustainable Business: Introducing a Typology from Business-as-Usual to True Business Sustainability', ${ }^{6}$ Professors of Sustainability, T. Dyllick and K. Muff suggest that although sustainability management is widespread among major companies, key questions such as "When is business truly sustainable?" and "How can we distinguish between those companies that contribute effectively to sustainability and those that do not?", still need to be answered. To date, the sustainability discourse has concentrated on reaching the UN SDGs with various performance measures, mainly focussing on global value chains (GVCs). For example, the ISO $26000^{7}$ standard on social responsibility (an alternative term for sustainability) sets out the 
willingness of the organization to incorporate social and environment considerations into its decision making and be held accountable for the impacts of its decisions on society and the environment. This article develops this line of thinking by introducing an 'innovation and monopolistic IP rights' dimension as an important consideration to supplement ISPO 26000 and corporate decision-making. It is important, in the author's view, given the role of private sector firms in 'fostering innovation' that leads to sustainable industrialization in the long term. Innovation comprises new ideas, devices or methods. ${ }^{8}$ Innovation also refers to the application of better solutions to overcome problems, barriers or to meet new developments, unarticulated needs or create new markets. ${ }^{9}$ Innovation occurs through the provision of new, original and improved products, processes, technologies and business models. ${ }^{10}$ As innovation is largely protected by monopolistic IP rights (such as patents, designs, trademarks and copyright as well as many other forms of IP) an IP theme necessarily emerges although the term IP is not expressly referred to in SDG 9. Inarguably, all companies, large and small, have IPRs, sometimes across multiple jurisdictions. They are corporate IP owners and their IPRs are regarded as corporate assets. With globalization, innovation and IPRs have achieved an unprecedented level of commercial importance within the virtual economy and the business community. However, one societal concern is sustainable economic progress and the impact of corporate ownership of monopolistic IP rights ownership at different points in the digital business life cycle, from start-up to global enterprise. The vast majority of companies view monopolistic IP rights ownership positively, they embrace and invest funds and resources in securing IP rights. However, the controversy lies with corporate strategy and decision making for commercialising their IP rights, which may adversely affect external stakeholders and potentially adversely impact on sustainability. However, while corporations have embraced IP rights ownership, there are arguments for and against the existence of IPR. The nature of these arguments will be highlighted in section 4 below. 
A company's business model sets the agenda for the type of IP rights and IP strategy relevant to the business. Therefore, at its heart, the pursuit of sustainable competitive advantage begins with a deeper understanding of the IP-reliant business model. A business model is a construct that describes how an organization creates, delivers and captures value a powerful means of understanding how the firm works at a fundamental level. A genuinely sustainable business can use its deeper understanding of innovation theory to create a significant positive impact in critical and relevant areas for society and the planet, rather than merely seeking to minimize its negative impacts. When well-defined and transparent, a business model provides insight into the key elements of the firm's potential impact on the GVC as well as the firm's capacity for business model adaptability, innovation and longevity as a sustainable business, leading to accountability. The insights presented in this article build on and add to the literature in the field as set out below.

\subsection{Background and literature}

There is little interdisciplinary academic literature concerning innovation and IP rights, business models and corporate longevity models per se. However, in 2009 Carlo MelendesOrtiz and Pedro Roffe published an edited collection of legal research entitled, Intellectual Property and Sustainable Development: Development Agendas in a Changing World ${ }^{11}$ which focused on several controversial issues such as the impact of monopolistic IPRs on the pharmaceutical sector, life forms, traditional knowledge, geographical indications and the role of competition within sustainable development. The following year Claude Henry and Joseph E. Stiglitz published their article 'Intellectual Property of Innovation and Sustainable Development' in Global Policy ${ }^{12}$, which examined the legal and economic foundations of innovation and IP for sustainable development. This approach saw them reflect on controversial issues such as access to health, global warming, competition law as well as open source innovation and software licences. They said, "We need to think of IP as only one aspect 
of a country's (and the world's) innovation system". ${ }^{13}$ This view supports the author's interdisciplinary approach, namely introducing the private sector, corporate angle which treats intangible IPRs as potentially valuable (but often hidden) corporate assets that support profitability in the short term, whilst providing a secure foundation for developing a CSR ethos and activities as the company grows and develops. The literature connection IPRs and CSR is beginning to emerge. There has been some recent work on IP, business models and CSR in the creative industries in the Brown and Waelde edited collection entitled, Research Handbook on IP and the Creative Industries. ${ }^{14}$ This volume gives incisive insight into the conflicted dynamics between IP and the creative industries, explaining that the impact of digital technologies gives rise to distinctly different cost structures, with considerably lower production and distribution costs that allow, but also offering opportunities for the creation of new goods, methods, markets, sources of supply and indeed, the reorganisation of entire industries. ${ }^{15}$ Chapter 25 CSR, IP and the creative industries will be discussed further in section 4, However this book does not specifically address the sustainability dimension. Appropriation of value is at the core of the business model concept and this in turn aligns business models with IPRs that have the potential to create future value for a firm. Here, we will examine how boards of directors address the corporate law legal requirement set out in section 172(1)A) Companies Act 2006 (CA 2006) to promote the success of the company and have regard to the likely consequence of decisions in the long term. How this could be done in the context of the new IP-reliant digital business models that companies devise, activate and adapt over time to sustain the firm is the fundamental gap in knowledge we seek to address and provides the rationale to study companies in the century club that have successfully adapted in the face of changes the business environment.

The IP and sustainability literature includes publications emanating from the World IP Organization (WIPO). ${ }^{16}$ The WIPO Secretariat participates as a UN Observer Organization at 
the Open Working Group on the SDGs (OWG) and at the inter-governmental negotiation and post-2015 Development Agenda. The WIPO Secretariat has also contributed to the various inter-agency work within the UN Chief Executive Board and with the work of the UN Task Team on Post-2015 Development Agenda, and the UN's Technical Support Team. Their most recent publication, the World IP Report 2017 - Intangible Capital in Global Value Chains examines the role of intangibles and IP rights such as technology, design and branding in international manufacturing adopting a macro-economic approach, using case studies to shed light on the importance of IP and other intangibles in modern production. The potential future impact of cutting edge technology is further analysed from an IPRs perspective in The Frontier Technologies for Sustainable Development World Economic and Social Survey 2018. ${ }^{17}$ This expert report deals with artificial machine intelligence, robotics, automation, electric vehicles, renewable energy, biotechnology and globalization which aims to illustrate the new technology trajectory wherein the commercial opportunities will be found to foster growth. In the $21^{\text {st }}$ century economic growth will increasingly depend on a foundation created through corporate IP ownership and IP-reliant business models.

Accordingly, optimizing a corporation's business model requires businesses to have a better understanding of innovation theory than is presently the case. An improved understanding of innovation theory would assist firms to become more agile when adapting to change in the commercial environment. In theory, such refined knowledge should assist firms to preserve their competitive advantage through strategic use of their corporate IP rights over the course of the business life cycle. IP-rich firms have a stronger foundation for commercial success and these rights assist to minimize the risk of insolvency. ${ }^{18}$ This research provides a deeper understanding of how IP-rich firms could contribute to the 'innovation', CSR and the sustainable industrialization envisaged in SDG Goal 9 over the next 15 years and beyond on their pathway to corporate longevity. 


\subsection{Methodology and structure}

The research and thinking presented below is multi-disciplinary and draws on academic fields such as corporate law, IP law, the innovation and sustainability literature. A mixed qualitative (non-numerical) business research method is used to connect corporate IP assets, corporate longevity, CSR and sustainability to improve our understanding the role of private sectors corporations in contributing to the achievement of UN 2030 SDG 9. It is inductive, constructionist and interpretive. In terms of method, we investigate and analyze existing legal and business management research on the theories and characteristics that relate to certain longlived companies in the 'century club'. The existing corporate longevity theory and characteristics of older, well-established global pharmaceutical firms established in the $17^{\text {th }}$ and $18^{\text {th }}$ centuries who successfully operate patent-reliant business models today is contrasted with a selection of six powerful much younger multinational enterprises (MNEs) that also operate IP-reliant digital business models. The comparison enables us to consider the implications of sustainable development activities for digital MNEs currently dominating the private sector. This multidisciplinary research contributes to theory and stock of knowledge in the sustainability field in the context of the UN 2030 SDG Agenda, with particular attention on SDG 9. Non-doctrinal research informs the problem, corporate practice, policy and recommendations.

The structure of this paper is as follows. We begin with a discussion of terminology from a corporate law perspective by examining the corporate stewardship theory and its comparable meaning from an IP law perspective. This is followed by an analysis of the characteristics that business management researchers have found lead to corporate longevity (the 'sustainable industrialization' contemplated by UN 2030 SDG 9). Next, we examine the theories of innovation (disruptive, sustained, closed and open) to develop a better understanding of how UN 2030 SDG 9 may be activated by private sector corporate actors in practice. We then 
evaluate a group of powerful young multi-national public companies (MNEs), among the largest corporate IP asset owners in the world and their incredibly successful IP-reliant digital business models. We assess the impact of their innovative business models and the potential of these digital MNEs to support the sustainable industrialization in the global digital environment.

An important outcome of this research is the finding that while newer firms mostly produce disruptive 'innovation' and patentable inventions - it is the older established firms that engage in a higher level of CSR activities and will likely make a greater overall contribution to achieving the SDG 2030 agenda.

The international initiatives undertaken in the UK, the EU and internationally by the World Intellectual Property Organization (WIPO) that support UN 2030 SDG 9 innovation and industrial sustainability are also evaluated. Finally, the paper concludes with recommendations that both corporate law and IP law have a role in shaping the behavior of leading digital MNEs to encourage them to play a greater role in supporting CSR activities in alignment with UN 2030 SDG 9. Such action could provide further support for IP-reliant business model innovation in the digital environment and CSR activities, especially in Africa which requires the most support in meeting SDG 9 by 2030. Section 2 critically discusses the concept and ethos of stewardship as a component of corporate longevity and sustainable industrialization.

\section{Corporate Stewardship and Sustainability: the Terminology}

In the corporate law literature and legislation, the term 'corporate longevity' or 'managing for long-term success' is more common than 'sustainable company', however this may be changing. Companies, as legally constructed persons, have a responsibility to act in the best interests of the company itself and more recently, the company's directors must take into account the impact of its activities on the wider society and in the long term. ${ }^{19}$ A shift from a traditional narrow focus on shareholder value to a broader concept of 'shared value' and the 
'long term view' is being shaped by the corporations law across many jurisdictions in the developed world. This corporate law evolution is aimed at developing a system of equity and justice that is more appropriate for $21^{\text {st }}$ century society and enterprise. ${ }^{20}$

In terms of sustainable industrialization, the corporate management research often focusses on companies that have existed for over a century to study how they have survived. Studying the 'survival factors' of such companies, terminology which downplays the fact certain companies have not only survived but thrived to become MNEs, is relevant to the sustainability discourse. The concept of sustainability is relatively new to the corporate law and management perspective and in the past, it was more narrowly associated with the environmental and green technologies movement. ${ }^{21}$

\subsection{The concept of stewardship in two disciplines: corporate law and IP law}

Another term, common in the corporate law discipline in the UK, yet increasingly relevant to the sustainability discourse is 'stewardship'. Stewards not only make responsible use of that which they hold on trust for the shareholders in the company, they must also strive to leave corporate assets in an enhanced condition for future generations. ${ }^{22}$ The 'stewardship' concept in UK corporate law has an ancient history, signifying its importance for the corporate law discipline. It traces its origins to mediaeval times and the steward's responsibility for bring food and drink to the castle's dining hall. ${ }^{23}$ Traditional corporate stewardship theory is that managers will act as responsible stewards of the assets they control and manage. Corporate stewardship theory predicts that a loyal steward of corporate assets will place a higher moral value on supporting the organization before his or her own personal interests. ${ }^{24}$ Stewards are assumed to be pro-organization and trustworthy. ${ }^{25}$ The concept of stewardship has evolved over the centuries and arguably the vast majority of UK directors and management now see themselves as 'caretakers' of their companies. Modern corporate law shapes the behaviour of company directors so for example, under the Companies Act 2006 (CA 2006), UK (hard law) 
company directors have an express legal obligation to make decisions to ensure the continuity of the company, in the best interests of the company, rather than for personal reasons or shortterm profit. ${ }^{26}$ This terminology is reflected in several corporate governance codes such as the UK Stewardship Code 2012 (an example of soft law). The Netherlands introduced the new Dutch Corporate Stewardship Code on 3 July 2018 affirmatively embracing the 'stewardship concept' ${ }^{27}$ According to Tomorrow's Company (2009):

The world needs responsible businesses stewarded by responsible shareholders. Without this joint and sustained commitment there will be too few companies which confidently and fully undertake their vital role in creating wealth and helping to address the societal and environmental challenges that humanity faces. However, while examples of stewardship can be found in the best private and family businesses, they become scarcer as shareholdings become more dispersed ${ }^{28}$

The UK's Financial Reporting Council (FRC) states that, 'stewardship' aims to promote the long term success of companies in such a way that the ultimate providers of capital also prosper. Effective stewardship benefits companies, investors and the economy as a whole. ${ }^{29}$ And further, 'In publicly listed companies responsibility for stewardship is shared. The primary responsibility rests with the board of the company, which oversees the actions of its management. Investors in the company also play an important role in holding the board to account for the fulfilment of its responsibilities. ${ }^{30}$ In the modern corporate context, stewardship is generally recognized as the acceptance of responsibility to safeguard the valuables of the company. The monopoly rights inherent in IP assets certainly have the potential to acquire value. Stewardship is a form of ethic that embodies the notion of service to others and responsibility for planning and managing resources such as the environment, nature, proprietary property $^{31}$ and information ${ }^{32}$. Sir Adrian Cadbury stated in the $U K$ Commission Report: Corporate Governance 1992 that: 
Corporate governance is concerned with holding the balance between economic and social goals and between individual and communal goals. The governance framework is there to encourage the efficient use of resources and equally to require accountability for the stewardship of those resources. The aim is to align as nearly as possible the interests of individuals, corporations and society.

The aim of good corporate governance under the UK Companies Act (CA 2006) is to align what is good for the company with what is good for society at large. ${ }^{33}$ In terms of potential corporate law reform, existing national corporate law obligations could be amended to mandate company directors of large and listed companies contemplate and report on their company's role in contributing to solutions to the urgent global problems expressed in the UN 2030 SDG Framework. The concept of 'enlightened shareholder value' is already enshrined in the CA 2006 s 172 (UK) duty that requires directors' to 'have regard to' the interests of the plurality of stakeholders and 'the likely consequences of any decisions in the long term' ${ }^{34}$ Companies, especially MNEs play a central role in society and nations across the globe, with access to enormous resources and power to position themselves to become 'stewards' of the future of humanity and the earth. ${ }^{35}$

The SDG 2030 Agenda will stand a better chance of success if governments are firstly able to imbue their corporate regulation with a 'stewardship' ethos and secondly, harness the resources and power of private MNEs, beyond their CSR activities in developed world, to solve global problems. Turning to SDG Goal 9 Innovation, whilst not wishing to downplay the valuable contribution of the public sector research institutes, universities and state development bank funding, there is a nexus with private corporations because the wider private sector is generally acknowledged as being the best source of innovation. ${ }^{36}$ However, research has also confirmed that public sector funding spurs private sector patenting. ${ }^{37}$ Yet currently public sector funding of innovation continues to decrease ${ }^{38}$ while technological complexity is on the 
increase as evidenced by patent filing and citations statistics. ${ }^{39}$ This misalignment also needs to be addressed at a policy level. The interrelationship between corporate stewardship, corporate longevity and sustainable innovation will now be explored.

\subsection{Stewardship, corporate intangibles and IPRs}

Company directors and executives are currently expected to act as stewards of and manage increasingly valuable amounts of 'intangible' corporate assets and IPRs. Intangible assets range from human capital and know-how to inventions, brands, designs and other intangible fruits of a company's creative and innovative capacity. In the realm of IP, the concept of stewardship is thought of quite differently. Eva Subotnik, in her work The Stewardship of Intellectual Property, ${ }^{40}$ considers the timescale further along from the creation of IP to the downstream stewardship and control of IP. This view is applied primarily copyright, which continues to exist for 70 years after of the death of the author or to trade marks, which may exist in perpetuity as long as the renewal fees are paid to the trade mark office of the relevant jurisdiction. Both types of IPRs are directly relevant to the new IP-centric digital technology companies to protect their software and brand. Helena Howe's work, 'Property, sustainability and patent law - could the stewardship model facilitate the promotion of green technology? ${ }^{41}$ She argues that, 'Finding the appropriate balance between the interests of IP owners and broader society is important for all aspects of IP, but in some contexts it becomes critical. ${ }^{42}$ She states further that an 'alternative property concept - that of IP stewardship - rather than strict IP ownership - would be better able to facilitate the flexible and differentiated solutions needed from patent law. ${ }^{43}$ The two interpretations of stewardship embrace the notion of the 'long term' as it relates to downstream control of IP which can last for decades and even centuries thereby playing a role in corporate longevity. Broadening the concept of corporate stewardship in its soft law codes, to explicitly recognise downstream control of IPRS in the long term and the aims of the UN 2030 SDG framework, especially SDG 9 is recommended. 
IPRs create multiple possibilities for creating future corporate value during their period of existence and have a direct role in protecting innovation and supporting unique core corporate strengths ${ }^{44}$ while ensuring long-term corporate success and profitability. The contribution of IPRs to corporate longevity is discussed further below.

\subsection{Transformative innovation and corporate longevity pathway}

Corporate innovation and a strong portfolio of exclusive monopolistic IPRs have the potential to be 'unique core strengths' and one of the foundations for corporate longevity in the $21^{\text {st }}$ century business environment. The duration, and therefore legal enforceability, of IP rights may be a surprise for those not familiar with the details. Governments provide the framework for the IP ecosystem by enacting legislation that facilitates, regulates and constrains the activities of IP owners.

Briefly, the UK and many other countries are signatories to the WTO Agreement on Trade Related Aspects of Intellectual Property (TRIPS) ${ }^{45}$ which provides that a copyright shall last for the life of the author plus 70 years, a trade mark can last indefinitely and a patent has a potential duration of up to 20 years (as long as regular renewal fees are paid otherwise the right will lapse and fall into the public domain available for others to use for free). While the durations of the different types of IPRs vary, the length of protection potentially provides long term commercial advantage for the owner and are a key consideration of an IP-centric company's business model. The duration of patent monopolies for example has the potential to last for a period of up to twenty years. Other IPRs (registered and unregistered) may exist for even longer and in the case of trademarks indefinitely - well beyond the year 2030 contemplated by the UN SDG Agenda. In the paragraphs that follow, we narrow our focus to IP-reliant business models in the digital economy.

The business environment is moving rapidly between what is being called the 'third' and the emerging technologies of the 'fourth' industrial revolution. The third revolution is the 
digital revolution, which since the mid- $20^{\text {th }}$ century, has involved the development of computers, the Internet, information and communication technologies. ${ }^{46}$ The fourth industrial is regarded as a new era due to disruptive technologies such as artificial intelligence, threedimensional printing, bionics, algorithms for quantum computers and personalised medicine. According to Professor Klaus Schwab, Founder and Executive Chairman of the World Economic Forum ${ }^{47}$ and author of The Fourth Industrial Revolution ${ }^{48}$, the new age is differentiated by the speed of technological breakthroughs, the pervasiveness of scope and the tremendous impact of new systems. ${ }^{49}$ Currently, the world is straddling the third and fourth industrial revolutions. The nature and impact of digital technologies is materially different to what has come before and appears to have disrupted traditional global value chains (GVCs). "Innovation is occurring at an accelerating speed, which is producing a number of challenges for institutional and governance frameworks throughout the world." said WIPO Director General Francis Gurry announcing the shift during the 2017 WIPO Assemblies. ${ }^{50}$ Depending on their business model and corporate objectives, companies add value via their corporate IP assets in different ways to achieve their business goals. This reflects growing corporate complexity in a world where intangible IP assets can be used strategically and provides the rationale for the recommendation that MNEs need to fully integrate an ethically responsible approach to IPRs ethos into decision-making, especially in the long term.

To achieve UN2030 SDG Goal 9 through transformative innovation there are three important elements to consider. The first element is the innovation itself. It opens the door to new possibilities and problem-solving, potentially making complex problems simpler and less expensive. A high level of non-obvious innovation may be potentially patentable as an invention. ${ }^{51}$ The innovative technology then leads to a 'business model innovation' to bring the technological solution to market and reach new users, the second element. The third element involves creating a new value chain or business system, which draws the innovator together 
with other participating companies and stakeholders to organize coherent economic models. We apply these three elements to identify a means to contribute to the achievement of UN 2030 SDG Goal 9.

\section{Corporate longevity, CSR and Sustainability: accelerating UN 2030 SDG Goal 9}

The corporate longevity management literature suggests that the average life span of firms is 12 to 15 years and only 40 per cent of all newly-created companies will be in existence after a period of 10 years. ${ }^{52}$ Of those companies that survive the first decade, the average life expectancy is 40-50 years or under half a century. ${ }^{53}$ Most companies do not survive the upheavals of change and competition over the long term. Indeed, the corporate lifespan of the Standard \& Poor 500 Index ${ }^{54}$ of companies has decreased by more than 50 years in the last century and less than 1 percent of companies will have a lifespan in excess of a century. ${ }^{55}$ Yet even so, some companies have existed and thrived for over a century and longer. Examples of companies across the globe in the 'century club' include the Hudson Bay Company (Canada), Dupont (USA), the Royal Dutch Shell Group (the Netherlands and the UK), Twinnings (UK), Lloyds Banking Group (UK), Mitsui (Japan), Sumitomo (Japan) and Daimaru (Japan). ${ }^{56}$ There is even a specific Japanese term for companies that have survived for more than a century, retained ownership within the same family and continued to operate in the same business sector - "shinise" firms. ${ }^{57}$ Japanese researcher I. Sasaki confirms that Kyoto, Japan's ancient capital, has the highest proportion century-old firms and that shinise firms are embedded in the communities where they are based; maintain family ownership; emphasise their commitment to the welfare of the community and put a strong emphasis on tradition and longevity. ${ }^{58}$ In a similar vein, Arie de Gues' research attributes the resilience of companies in the century club on the basis that 'long-lived companies are sensitive to their environment...whether they had built their fortunes on knowledge such as Dupont's technological innovations or the Hudson Bay Company's access to the furs and forests of 
Canada'. ${ }^{59}$ Of course many other countries have companies in the century club that are not mentioned here.

However, in the $21^{\text {st }}$ century, the average age of the top companies is shrinking (see Figure 1 below). Indeed, Facebook, Inc., Amazon, Inc. Apple, Inc., Netflix and Google (collectively known as the 'FAANGS' ${ }^{60}$ ) are now some of the youngest, yet largest powerful public companies in the world. These technology giants all operate IP-reliant digital business models and were started by entrepreneurs and their friends, rather than families as seen in Figure 1 below. UN SDG 9 is premised on the basis that:

...technological progress is key to finding last solutions to both economic and environmental challenges. Further, promoting sustainable industries and investing in science, research and innovation are all important ways to facilitate sustainable development.' However, in terms of the rise in IP-reliant digital business models, more than 4 billion people do not have access to the Internet and more than $90 \%$ of these are in the developing world. ${ }^{61}$

The FAANGS are well-placed to have a role in bridging this digital technology divide. However, as relatively young companies, albeit very large powerful ones and in jurisdictions without soft law corporate governance codes embracing stewardship, their CSR activities have had less time to ripen, while their directors have focused on rapid growth, innovation and the journey from start-up to listing as a public company. ${ }^{62}$ In contrast, consider the shinise approach elaborated by the President of Unsoudou, a 128-year-old company producing wood block prints and art books who states, 'We do not publicly list our stocks. Our way of doing is the opposite of this. We do not want to make profit in the short term. ${ }^{96}$ Shinise down play short term profit and eschew rapid growth, preferring a cautious approach to innovation as one aspect of a long corporate history. 
The pharmaceutical sector business model is heavily reliant on the validity of patents to protect active ingredients of key medicinal products. ${ }^{64}$ Interestingly, most of the largest and most successful firms in the industry are in the century club and originated in the second half of the $19^{\text {th }}$ century. The data presented in Figure 1 below is gleaned from R Walsh's article 'A history of the pharmaceutical industry' ${ }^{65}$ and certain statistics of the 2019 rankings of the largest multinational pharmaceutical firms.

Figure 1 Pharmaceutical Firm in the Century Club and performance in 2018

\begin{tabular}{|c|c|c|c|c|}
\hline Pharmafirm & $\underline{\text { Year Founded }}$ & $\underline{\text { Age }}$ & 2018 Market Share & $\underline{\text { USD Revenue }}$ \\
\hline Merck & 1668 (Germany) & 351years & $3(4.44 \%)$ & 5 (42.03 Billion) \\
\hline GSK & 1715 (UK) & 304 years & $6(4.19 \%)$ & 4 (43.14 Billion) \\
\hline Pfizer & 1849 (USA) & 170 years & $1(5.6 \%)$ & 2 (53.6 Billion) \\
\hline Bayer & 1863 (Germany) & 156 years & $9(2.84)$ & 3 (45.06 Billion) \\
\hline Eli Lilly & 1876 (USA) & 143 years & $10(2.57 \%)$ & 6 (24.56 Billion) \\
\hline Roche & 1896 (Switzerland) & 123 years & $2(5.44 \%)$ & 1 (58.86 Billion) \\
\hline
\end{tabular}

Source: R. Walsh and Forbes 2019 data

Each of the pharmaceutical firms in the century club in Figure 1 above, continue to thrive and rank in the top ten in 2018 in terms of market share and revenue. In 'Corporate Social Responsibility in Global Health: an exploratory study of multinational pharmaceutical firms' published in $2015^{66}$, the authors combined data on the year of founding against market share, revenue and CSR ranking. They found that the primary factors motivating CSR engagement were: reputational benefits, recruitment and employees satisfaction, better rankings in sustainability indices, entrance into new markets, long term economic returns and improved public health. The common CSR activities of these pharmaceutical firms involved differential pricing, strengthening developing country distribution infrastructure, health initiatives and targeted R\&D. However, they advised that pharmaceutical firms are special 
cases because their business decisions directly impact on human health making CSR efforts particularly important. ${ }^{67}$ By comparison, the FAANGs are young, relatively immature, albeit immensely powerful IP owning companies, and appear to have less corporate motivation to engage in CSR in lesser developed countries. The question is, does their relatively short corporate lifespan impact on their ability and willingness to engage in CSR activities, one of the pillars of which is sustainability? Other management research studying firm maturity in a broader context is discussed below to further enrich the analysis.

\subsection{Firm maturity, CSR, Innovation and Sustainability}

Research in 2015 exploring the effect of firm maturity on CSR based on over 26,000 observations across 21 years revealed that mature firms invest significantly more in CSR. ${ }^{68}$ The study demonstrated that as companies get older, they become more responsible in terms of diversity and environmental awareness, whereas the effect of firm aging is much weaker in terms of human rights and product safety. This study was the first to link corporate life cycles to CSR. ${ }^{69}$ The advantages of corporate longevity for achieving the UN 2030 SDGs are potentially multi-fold. Employees, customers, suppliers and communities all benefit from company longevity.

Another important factor was identified by Tenhaken who studied the group of companies whose lifecycle exceeds a century. Her study indicated that century old companies were more likely to be family owned, or privately held, non-public companies leading to her conclusion that remaining a privately owned company is a key factor in their survival over the long term. ${ }^{70}$ Companies in the century club have had to continually innovate to adapt and survive decades of technological change. This incredible corporate history of managing innovation, resources and human capital is a type of valuable, similar to the way in which unicorn start-ups are eagerly studied in the entrepreneurial sector. Firms in the century club should be viewed as role models for younger firms in the digital environment. Tenhanken's research supports de 
Gues' proposition that companies are human communities, rather than pure economic machines. Applying this thinking to the FAANGs, relatively young public companies (the opposite of what is predicted to produce sustainable industrialization and innovation) will be illuminating. Later in this article, the business models of a sample of multi-national digital companies are critically examined to assess how sensitive each company is to their environment, qualitatively evaluating the relationship between business models, longevity and sustainability. The next section explains innovation theory and applies the key concepts of sustaining and disruptive innovation to elaborate our interdisciplinary understanding of UN SDG Goal 9 in practice in the global digital economy.

\subsection{Innovation theory and accelerating UN 2030 SDG 9}

One component of UN 2030 SDG 9 is the concept of 'innovation' which is needed to drive more efficient and better use of current environmental and human resources to sustain a population of 8.5 billion by $2030 .^{71}$ For the last two decades, the classical theory of innovation has been influential in commerce and a valuable means of predicting which companies will live long and prosper so as to provide the benefits of corporate longevity outlined in sections 2.4.1 and 2.4.2 above. In 1962, Everett Rogers, Professor of rural sociology, published his seminal work: Diffusion of Innovations. ${ }^{72}$ The diffusion of innovation theory seeks to explain how, over time, an idea or product gains momentum and the rate it diffuses (spreads) through a specific population or social system. Rogers suggests four main elements influence the spread of a new idea: the innovation itself, communication channels, time and a social system. The innovation must be widely adopted if it is to become self-sustaining. Further, his research indicates that within the rate of adoption, there is a point at which an innovation reaches critical mass or tipping point. He classes adopters as innovators, early adopters, early majority, late majority, and laggards. ${ }^{73}$ It will be vital for companies to understand the dynamics of innovation, how and where in the innovation timeline their business models fits, so that they 
can operative sensitively in their environment. More corporate awareness on the part of corporate boards and their directors and managers of innovation theory could have a positive impact on making solving global sustainability problems in the context of UN 2030 SDG 9 more efficient and effective.

\subsection{Disruptive versus sustaining innovation}

There are two main types of innovation. A disruptive innovation is one that helps create a new market and value network, and eventually disrupts an existing market and value network (over a few years or decades), displacing an earlier technology. ${ }^{74}$ Disruptive innovation has the most potential impact on a company's business model because it reinvents a technology or invents an altogether new (non-obvious) solution which may be potentially patentable. IP literacy will provide the company with valuable patents and monopoly property rights which may deliver a competitive advantage and have an economic impact on competition. While there are many examples, two highly successful cases are Airbnb, Inc. ${ }^{75}$ and Uber ${ }^{76}$, companies that harnessed digital platforms to develop new business models, create new markets and disrupted the status quo within the business environment.

In contrast, a sustaining innovation is an incremental innovation that enables or improves an existing product. It does not create new markets or values, rather develops the existing business environment. The "innovator's dilemma" is the choice a company makes when choosing between holding an existing market share by doing the same, yet slightly better (sustaining innovation), or capturing new markets by embracing new technologies and adopting new business models (disruptive innovation). ${ }^{77}$ Disruptive innovation and sustaining innovation may be complementary rather than mutually exclusive alternatives. Sustaining innovation arises from listening to the needs of consumers in the existing market and creating products to satisfy their predicted future needs (see sensitive evolution in section 2.5 above). 
Disruptive innovation creates new markets unconnected to the mainstream; potential markets that are unknowable at the time of the technologies conception. ${ }^{78}$

\subsection{Preliminary findings}

In theory, for the powerful digital MNE companies to create a long-lasting (sustainable) innovation, they need to aspire to two things:

(1) continue to achieve both revolution (disruptive innovation) and sensitive evolution;

AND

(2) move toward increased family, employee or other private share ownership (opposed to public ownership) over time, which typically leads to the delivery of a higher level of CSR and sustainability initiatives.

Although only half way in its journey to joining the ranks of the century club, an example of a company that successfully achieved (1) and (2) above is the privately held British multinational conglomerate Virgin Group Ltd. In 1970 Sir Richard Branson and Nik Powell formed a firm called Virgin, a mail-order record company which is still headquartered in London, UK. The company grew rapidly and entered new markets and is currently in banking, publishing aviation, commercial spaceflight, consumer electronics, film, health care, jewellery, Internet, mobile phones, music, radio, retail and travel. ${ }^{79}$ The Virgin Group Ltd now comprises over 400 companies. Virgin listed as a public company in 1986. However, following the 1987 stock market crash, the company went private again in 1988 through a management buyout and has remained privately held ever since. As predicted, the company's interest in CSR activities grew over time. On 21 September 2006 Branson pledged to invest the profits of Virgin Atlantic and Virgin Trains in research for environmentally-friendly fuels. In 2007, Branson announced the company was establishing a new global science and technology prize, The Virgin Earth Challenge ${ }^{80}$, in the belief that such prizes encourage technological innovation for the good of the earth. More recently, Virgin has entered the commercial space flight market (innovation 
reliant) some of which may find its way to innovative uses on earth in support of SDGs 9. The key point is that practical implementation of private (as opposed to public) innovation has the potential to make a potentially more meaningful impact in the market or society and it occurs via a business or revenue model. Having set out innovation theory, next we discuss the IPR legal framework that has evolved to encourage and support innovators and innovation in the context of UN 2030 SDG 9.

\section{The IP rights legal framework to accelerate UN 2030 SDG 9}

Although monopolistic IP rights such as patents, designs, trademarks and copyright among others are not specifically mentioned in the UN 2030 Sustainability Agenda, the IP legal framework is a relevant topic in the field of sustainability given its role in supporting innovation. Law and legal frameworks have an important role in sustainable development. ${ }^{81}$ In the IPR legal framework, 'innovation' is a broader concept that is related to, but differs from the term 'invention' which has a very precise legal definition under patent law principles: s 1 Patents Act 1977 (UK) (PA 1977). UN 2030 SDG 9 contemplates innovation broadly defined. Not every innovation will be patentable or meet the legal requirements for patent protection. The patent law system is devised to support the strongest inventions, in essence, to give them a monopoly or competitive advantage - in other words, a head start on the competition. They receive additional legal monopoly protection for a time-limited period if they meet certain strict legal criteria and successfully navigate the patent examination process which includes disclosure (publication) of how the invention works. Once the term of patent protection expires, this 'innovation' knowledge falls into the public domain and can be freely used by others. In terms of legal theory, the IP law regime attempts to strike a balance between the conflicting interests of society as a whole in the quality of life development and the interest of the individual or corporate legal person to secure a "fair" value for its intellectual effort or investment of capital or labour. Our global international society and institutions ${ }^{82}$ support the 
granting of monopolistic IP rights, in brief, to encourage innovation and solutions to longstanding problems; reduce investment in innovation, avoid duplication and minimize the problem of free-riders. ${ }^{83}$ In economic terms, the long-term benefits that accrue from IP rights act as incentives to promote innovation and this is the traditional justification for governments' granting them. This rationale and justification arises despite the fact that allowing free copying (an IPR infringement if copied without permission) would yield short-term benefits given that products incorporating the IP could be priced close to marginal cost. Therefore, key questions for those studying in the field of sustainability as it relates to the IP law regime is whether the promotion of incentives such as monopolistic IP rights are in the public interest or do they diminish sustainability? Although there are several views on the answer to this question, in the author's opinion at the highest level of analysis, IP rights and competition policies are complementary because they share a concern to promote technical progress by supporting innovation in the short term to the ultimate benefit of the public in the long term. ${ }^{84}$ In the same vein, although the UN's 2030 Sustainability Agenda is now only 12 years away, the innovations of today will ultimately benefit the public beyond 2030 in the much longer term.

Companies are more likely to invest in innovation if they are at least somewhat legally protected against 'free-riding'. ${ }^{85}$ In economics, the free-rider problem occurs when those who benefit from resources, public goods, or services do not pay for them, which results in an under provision of those goods or services. ${ }^{86}$ The innovations to overcome issues identified in the 17 UN 2030 SDGs to end poverty, create employment, protect the planet and bring prosperity to all by 2030 are estimated to cost $\$ 5-7$ trillion USD to finance. ${ }^{87}$ Innovation requires investment which will only be achieved using private capital as well as public investment provided by international institutions and national governments. In Capitalism with Capital (2017) Jonathan Haskel and Stian Westlake explore the unusual economic characteristics of intangible investment and discuss how an economy rich in intangibles is fundamentally 
different from one based on tangibles. ${ }^{88}$ Similarly, this article investigates how companies and policy makers can exploit the characteristics of intangibles, innovation and IP-reliant business models in the digital age to support the UN 2030 SDGs.

Almost every innovation, disruptive or otherwise, begins as a small-scale experiment. ${ }^{89} \mathrm{It}$ is rare that a technology or product is inherently sustaining or disruptive. It is at this point in the business lifecycle that legally constructed monopolistic IP rights and, in particular, patent protection for innovation, is vitally important. In essence, patent rights protect new, industrially applicable inventions and give the inventor or proprietor ('the patentee') a legally recognised monopoly to work the invention for a period of up to 20 years. ${ }^{90}$ A patent is governed by national laws, and also by international treaties, when those treaties have been given effect in domestic law, providing exclusive rights only in the jurisdiction and not in any other country. Patents are legal instruments intended to encourage innovation by providing a limited monopoly to the inventor (or their assignee) in return for the disclosure of the invention. Publication of the invention is mandatory to be awarded a patent. ${ }^{91}$ The patent law system recognises that innovation and technological developments, both crucial tools for a country's financial and social wealth, cannot be motivated solely by market competition. The increase in the number of patents filed worldwide over the last two decades and the growth of the markets for these assets is an important global trend and is intrinsically linked to innovation on a global scale. ${ }^{92}$ IP and patents in particular, are a normal occurrence in the modern business landscape. A key commercial advantage of a patent monopoly is that it can prevent unauthorised third parties from using the invention for a limited period. While under monopoly protection, in the UK the Patent Act 1977 provides that only the patentee is lawfully allowed to commercially exploit the invention. ${ }^{93}$ The scope of that right in any particular case is determined by the claims in the patent specification. ${ }^{94}$ Further, there is strong evidence pointing to a positive association between patenting and measures of company financial 
performance. ${ }^{95}$ Patenting is correlated with superior performance, as indicated by a company's sales of innovative products and growth in employment. ${ }^{96}$ Companies with innovations that are new to the market are considerably more likely to patent. ${ }^{97}$ Further, companies usually prefer patents over the cost and inconvenience of maintaining their inventions secret (although un-patentable "know how" may need to be kept confidential). Typically, companies that apply for patents have undertaken at least a basic commercial strategic analysis of the pros and cons of patenting and arrived at a considered conclusion that the benefits of obtaining a monopoly over their invention exceed the costs and that patent rights will provide stronger protection than keeping the invention confidential ${ }^{98}$ or defensive publication. ${ }^{99}$ Strong patents (certain validity) are preferred over weak patents (at risk of being invalidated). However, even weak patents have their strategic uses which should be borne in mind.

At the beginning of the business life cycle, start-ups and SMEs have fewer IP rights, whilst large private and public companies typically own more IP rights with proven income streams which contribute to market dominance. Consequently, all companies, large and small, have IP rights, often-time limited and sometimes across multiple jurisdictions. They are corporate IP owners and this gives them unique opportunities to exert commercial control leading to commercial success and corporate longevity. The IP rights legal framework is designed to protect innovation and has achieved an unprecedented level of commercial importance in the new world of globalization in the knowledge economy. Start-up and micro-entities initially have few assets other than their innovative ideas (intangibles). Therefore, granting property rights to these intangibles would seem to ensure the ability of the new company to grow without the threat of immediate imitation. ${ }^{100}$ Patents operate as one of the posited benefits of the IP law framework, especially for start-ups where patents acts as a quality signal for potential innovative solutions to problems and convey information to financiers and investors. ${ }^{101}$ At first glance, is it difficult to understand how laws that provide monopolistic exclusionary rights 
on the one hand can promote sustainable arts and sciences that benefit our society on other. However, in terms of sustainable business models, while IP rights restrict the freedom of the immediate generation, their limited scope and potentially lengthy duration ensure, in theory at least, that they promote the freedom of future generations by encouraging innovators to continue to create, invent and disseminate once the IP right has expired. In the author's opinion, widely shared although not without critics, IP rights should be viewed as a mechanism to promote innovation, competition and SDG 9 sustainable industrialization. By restricting competition through the creation of a monopoly over the production of goods and services in the short term, many believe ${ }^{102}$ that IP rights promote competition at the higher innovation level which ultimately benefits the public in the longer term. On this basis, we can argue granting IPRs has a role to play in progressing the UN 2030 Agenda for SDG 9.

However, there is a voluble case against monopolistic IP rights in pursuit of sustainability and SDG 9. ${ }^{103}$ At the forefront of this movement are Michele Boldrin and David Levine, who argue that:

Current legislation on intellectual property confuses the protection of property rights on objects in which ideas are embodied with the attribution of monopoly power on the idea itself and, furthermore, with restrictions on the usage of such goods on the part of the buyers. This implies that both patent and copyright laws should be dramatically altered. To back up our claim we provide theoretical arguments, even for the most extreme case in which goods are produced at a positive fixed cost and zero marginal cost. $^{104}$

In my view, this thinking is flawed as IP rights protection is necessary, especially at the early stages of the business life cycle to protect the innovator from free-riding and to give entrepreneurs and small-to-medium sized firms an opportunity to thrive. The problem arises with the enormous monopoly power wielded by large private, public and multinational 
companies. We saw earlier that the corporate governance 'stewardship' concept could be a solution if adopted beyond the UK, the Netherlands. In my view, it is unnecessary to claim that the fundamentals of both patent and copyright laws should be dramatically altered to reduce legal protection for innovation. ${ }^{105}$ There are other legal responses that could provide solutions. Competition law and the compulsory licence systems already exist to check monopoly power, but need to be updated and extended to include modern sustainability issues.

\section{A competition law response to monopoly power}

'Monopoly power' is traditionally dealt with by national competition legislation ${ }^{106}$ to reduce the unfair impact of monopolies, including IP monopolies. Professor Timothy Wu at Columbia University Law School, the author of The Curse of Bigness: Antitrust in the Gilded Age agrees. ${ }^{107}$ Profess $\mathrm{Wu}$ is especially concerned about the extreme corporate concentration in the banking, pharmaceutical and technology sectors, including most recently, the behaviour of the FAANGs, giant technology firms. Professor Wu suggest that their monopoly power is best tempered controlled for the benefit of the economy and society via competition law ('anti-trust' law in American terminology) through the adoption, for example, of 'market investigation' practice in use in the UK, among his other recommendations which are beyond the scope of this paper. In my view a strengthened competition law response to corporate monopoly power is a more realistic and pragmatic economic and political response than dramatically altering patent and copyright law, as suggested by Boldrin and Levine cited above.

Further, the IP rights regime already has a system of compulsory licensing which occurs when a government allows someone else to produce the patented product or process without the consent of the patent owner. In current public discussion, this is usually associated with pharmaceuticals, but it could also apply to patents or IP rights in any field. ${ }^{108}$ 
For example, a pharmaceutical company can be ordered to licence the use of their pharmaceutical products in certain lawful circumstances e.g. a national public health emergency. A reinvigorated response to monopoly power through compulsory licensing is canvassed next.

\subsection{Reinvigorated response to monopoly power: potential to amend article 27(2) TRIPS:} compulsory licensing

Fresh thinking leads me to suggest a more positive way for the IP rights system to evolve for the benefit of all stakeholders, namely, to update and amend the WTO TRIPs Agreement to expressly address sustainability. Article 27(2) already provides that WTO members may exclude from patentability inventions, the prevention within their territory of the commercial exploitation of which, is necessary to protect ordre public or morality, including to protect human, animal or plant life or health or to avoid serious prejudice to the environment, provided that such exclusion is not made merely because the exploitation is prohibited by their law. This TRIPS flexibility could and perhaps now should also be used in a 'sustainability' context.

The grounds for granting a compulsory licence could be expanded to include 'sustainability' emergencies, while upholding the legitimate interests of the patent holder. If a compulsory licence is issued, adequate remuneration must still be paid to the patent holder (Article 31 h). However, for 'national emergencies', 'other circumstances of extreme urgency' or 'public non-commercial use' (or 'government use') or anti-competitive practices, there is no need to try for a voluntary licence (Article 31b). Further, compulsory licensing must meet certain additional requirements - it cannot be given exclusively to licensees (e.g. the patent-holder can continue to produce), and usually it must be granted mainly to supply the domestic market. ${ }^{109}$ 
Such new legal responses could have a significant impact on achievement of the UN SDGs, whilst ensuring the IP owner receives adequate remuneration to remain in the black in terms of profitability in order to achieve corporate longevity, provide employment, pay tax and support CSR activities. Continuing in our analysis of corporate innovation, we turn to the issue of closed versus open innovation which will also inform the UN 2030 SDG 9 discourse.

\subsection{Closed versus open innovation and the viability of CSR}

Traditional innovation adopts a 'closed' approach, perhaps best epitomized in the UK by the old automotive giants such as Vauxhall and BMW, now being challenged by Tesla's electric vehicles, an example of disruptive innovation. ${ }^{110}$ Closed innovation involves applying research to product development, manufacturing and sales and is frequently done in house, via subsidiaries, or carefully managed licensees and contractual arrangements. Within Apple, Inc. for example, there is an almost singular focus on research and development (R\&D) in its long line of mobile electronic devices with the company using a combination of open and closed innovation. An example of closed innovation is the development of a new iPhone whereby no technological information is released until the official product launch date. ${ }^{111}$ Apple, Inc. also uses open innovation when they collaboratively solve problems with third parties and when licensing their patented invention and know how to other people and organisations. ${ }^{112}$ Henry Chesborough is credited as the 'father of open innovation' as a result of his seminal publication, Open Innovation: Researching a New Paradigm published in 2008. ${ }^{113}$ Chesborough described a model of innovation whereby firms draw on third party $\mathrm{R} \& \mathrm{D}$ and the limits of corporate open innovation. For example, while putting the innovation information in the public domain, or providing open source royalty-free technologies is possible (and many advocate doing so) from a commercial perspective taking these steps prevents the development of a revenue stream. 
One can hypothesize, that with less profit, the SDG 9 goal of sustainable industrialization is less likely to be achieved and less resource devoted to CSR activity. As we learned in section 2.3 above, a correlation between corporate longevity and contribution to CSR activities exists. The author understands, albeit anecdotally, that share and pension fund managers are currently developing algorithms to track corporate CSR initiatives, as the lack thereof tends to indicate poor profitability and in the extreme, risk of insolvency. On the other hand, open innovation could still be used to collaborate, while contemplating the payment of a licence fee for use of the corporate IP, rather than free use. This approach facilitates revenue which underpins corporate longevity, as well as access to information, a key driver of innovation contemplated by UN 2030 SDG 9. If innovations emerge and they are socially accepted, then the next phase is to scale them up. From a corporate perspective, there is more to be gained financially from serving a large market over a small market. Many lesser developed countries (LDCs) have very large markets but lack the infrastructure to fully benefit as yet from the digital economy. We have shown how IPRs, innovation, new technologies and corporate longevity are intrinsically linked with IP-rich sustainable industrialization contemplated by SDG 9. Nest we contemplate how the digital environment has transformed the commercial environment, spawning the FAANGS and their new disruptive IP-reliant digital business models, whose role in CSR and sustainability efforts is in question due to their youth and immaturity.

\subsection{Understanding the role of young digital MNEs in accelerating SDG 9}

This article shines a spotlight on digital and IP-reliant business models that operate in the intangible (or virtual) economy, straddling the third and fourth industrial revolutions and disrupting traditional GVCs. In a remarkably short period of time certain formerly small and medium-sized enterprises (SMEs) have successfully leveraged the digital economy and their IP to become multinational enterprises (MNEs). For example, Apple, Inc. followed a 
disruptive innovation path by building a web of applications to make the iPhone more like a miniature personal computer. The UN Conference on Trade and Development (UNCTAD) has mapped the digital economy by classifying relevant MNEs into two groups. ${ }^{114}$ The first group include the digital MNEs characterized by the central role of the internet in their operating and delivery model. They include purely digital players (internet platforms and providers of digital solutions) that operate entirely in a digital environment and mixed players (e-commerce and digital content) that combine a prominent digital dimension with a physical one. The second group is the information and communication technology (ICT) MNEs that provide the enabling infrastructure to make the internet accessible to individuals and businesses. The latter includes IT companies selling hardware and software, as well as telecom firms.

Continuing our small scale exploratory study which began in Figure 1 above with pharmaceutical firms in the century club, we see that all the companies included in our sample in Figure 2 below are examples of modern digital companies who feature in the Forbes Global 2000: The World's Largest Public Companies 2018 rankings. ${ }^{115}$ Figure 2 identifies the eight largest players in terms of operating revenues as of 2018. The selection criteria were that the company must be a digital MNE with a business model that uses Internet platforms, digital solutions, e-commerce or provides digital content. Figure 2 also confirms the age of the digital MNE in years using the year the company was founded.

Figure 2 Number of years from foundation to Multi-national Enterprise (MNE)

\begin{tabular}{cccc}
\hline MNE & Founded & $\begin{array}{c}\text { From } \\
\text { SME to } \\
\text { MNE }\end{array}$ & IP-reliant digital business model \\
\hline UBER & $\begin{array}{c}\text { Founded 2009 by Travis } \\
\text { Kalanick and Garrett Camp, } \\
\text { HQ in San Francisco, } \\
\text { California USA, now } \\
\text { operates worldwide in 633 } \\
\text { cities. }\end{array}$ & 9 years & $\begin{array}{c}\text { Taxi drivers are the customers, rather than } \\
\text { the customers who use the taxi. Uber is an } \\
\text { "agent" connecting the actual "merchant," } \\
\text { the driver, with a customer over its app } \\
\text { platform. It derives revenue by taking a fee } \\
\text { for the service. }\end{array}$ \\
\hline Airbnb, Inc. & $\begin{array}{c}\text { Founded in 2008 by Brian } \\
\text { Chesky (CEO); Joe Gebbia }\end{array}$ & 10 years & $\begin{array}{c}\text { Airbnb is an online marketplace connecting } \\
\text { travellers with local hosts. Airbnb offers free }\end{array}$ \\
\hline
\end{tabular}




\begin{tabular}{|c|c|c|c|}
\hline & $\begin{array}{c}\text { (CPO); Nathan Blecharczyk } \\
\text { (CTO) in San Francisco, } \\
\text { California, USA. }\end{array}$ & & $\begin{array}{l}\text { listings to property owners and enables } \\
\text { travellers to browse the listed spaces. The } \\
\text { revenue model comprises booking and } \\
\text { monetary transactions over Airbnb's } \\
\text { platform: a flat } 10 \% \text { commission from } \\
\text { property owners on each booking and a 3\% } \\
\text { transaction fee from travellers. } \\
\text { Airbnb is present in over } 190 \text { countries. } \\
\text { Al7 }\end{array}$ \\
\hline Facebook, Inc. & $\begin{array}{c}\text { Founded in } 2004 \text { by Mark } \\
\text { Zuckerberg, USA }\end{array}$ & 14 years & $\begin{array}{l}\text { Facebook is the world's most popular social } \\
\text { network with } 1.13 \text { billion daily users. It has a } \\
\text { diversified business model, owning several } \\
\text { companies e.g. Instagram. Generates revenue } \\
\text { from advertising \& user account data. }\end{array}$ \\
\hline Alibabagroup.com & $\begin{array}{l}\text { Founded in } 1999 \text { by CEO } \\
\text { Daniel Zhang, HQ in } \\
\text { Hangzhou, China. } \\
\text { Internet \& Catalogue Retail. } \\
\text { Market Cap: } \$ 499.4 \text { Billion }\end{array}$ & 19 years & $\begin{array}{l}\text { Alibaba is a pure e-commerce company in } \\
\text { China, operating an online platform as a } \\
\text { middleman between buyers \& seller through } \\
\text { its extensive network of websites. The largest } \\
\text { site, Taobao, operates as a fee-free } \\
\text { marketplace. Sellers pay to rank higher on } \\
\text { the site's internal search engine, generating } \\
\text { advertising revenue for Alibaba. }{ }^{118}\end{array}$ \\
\hline
\end{tabular}

\begin{tabular}{|c|c|c|c|}
\hline Netflix & $\begin{array}{l}\text { Founded in } 1997 \text { by Reed } \\
\text { Hastings and Marc } \\
\text { Randolph, in Scotts Valley, } \\
\text { California, USA. Price to } \\
\text { earning (P/E) ratio of } 268 \\
\text { (Investors have paid } \\
\text { \$268USD for every \$1USD } \\
\text { the company makes. }{ }^{119} \\
\end{array}$ & 21 years & $\begin{array}{c}\text { Netflix operates a video, TV and film-on- } \\
\text { demand online service where clients using } \\
\text { video streaming technology in return for } \\
\text { monthly membership fees. }\end{array}$ \\
\hline Amazon.com & $\begin{array}{l}\text { Founded by Jeff Bezos in } \\
\text { 1994, USA. } \\
\text { Internet \& Catalogue Retail } \\
\text { Market Cap: } \$ 777.78 B\end{array}$ & 14 years & $\begin{array}{l}\text { Amazon is an online direct retailer for new } \\
\text { and used goods charging a small mark-up. } \\
\text { Inventory is stored in a large network of } \\
\text { warehouses. Amazon provides a platform for } \\
\text { other retailers to sell products retaining a } \\
\text { percentage of sale price, as commission. } \\
\text { Amazon has a subscription-based revenue } \\
\text { model through its Amazon Prime service It } \\
\text { also generates revenue from selling the } \\
\text { Kindle e-reader and in application } \\
\text { purchases. }{ }^{120}\end{array}$ \\
\hline Apple, Inc. & $\begin{array}{c}\text { Founded in } 1976 \text { by Steve } \\
\text { Jobs, Steve Wozniak and } \\
\text { Ronald Wayne, California, } \\
\text { USA. } \\
\text { Market cap: } \$ 926.95 \text { Billion }\end{array}$ & 22 years & $\begin{array}{l}\text { Apple's business model ensures control over } \\
\text { its multi-channel platform, relying on the } \\
\text { integration of content (software, media, and } \\
\text { apps) and hardware (laptops, phones, and } \\
\text { tablets) to drive growth. }{ }^{121}\end{array}$ \\
\hline $\begin{array}{c}\text { Spotify } \\
\text { Technology SA }\end{array}$ & $\begin{array}{l}\text { Founded in } 2006 \text { by Daniel } \\
\text { Ek and Martin Lorentzon } \\
\text { specialising in music, } \\
\text { podcast and video streaming } \\
\text { services launched in } 2008 \text { in } \\
\text { Stockholm, Sweden. It } \\
\text { became a public company in } \\
\text { April } 2018 \text {. } \\
\text { Market cap of } \$ 27 \text { Billion. }\end{array}$ & 12 years & $\begin{array}{l}\text { Spotify provides a digital rights management } \\
\text { (DRM)-protected content platform for music } \\
\text { and media companies. The business model is } \\
\text { a 'freemium service'; basic features are free } \\
\text { with advertisements or limitations, while } \\
\text { additional features, such as improved } \\
\text { streaming quality and music downloads are } \\
\text { offered via paid subscriptions. }\end{array}$ \\
\hline
\end{tabular}

Sources: Compiled by the author from information published by Forbes in 2018

\subsection{Analysis and commentary}


In Figure 2 above we observe that the newest MNEs with digital business models have been in existence 22 years or less, yet they are currently leading the digital revolution. Incredibly, the youngest MNE is only 9 years old. Their business models are reliant on information technology and digital platforms, were founded by men and are mostly US-based enterprises. These statistics are largely mirrored in WIPO and EPO patent filings which show that the United States is at the apex of prolific patent filers and the vast majority of inventors recorded on patent documents are men. ${ }^{122} \quad$ IP-reliant digital business models have a concentrated geography and most digital MNEs are from developed countries, in particular, the US has been very successful at developing and financing radical ideas, especially in relation to the digital economy ( 5 of the 8 top ranking digital MNEs) with the other digital MNE being based in the PRC and Sweden. This finding is echoed by that of UNCTAD, whose data indicates that the share of digital MNEs based in the US is almost two thirds. Their predominance, coupled with their tendency to retain most tangible assets in their home country, results in a geographic distribution of subsidiaries that is highly skewed towards domestic companies based in the US. From the point of view of sustainable industrialization, operating and delivery models that rely on high levels of digitalization tend to result in lighter international and environmental footprints. ${ }^{123}$ The more MNEs rely on the internet, the better they can leverage their foreign assets, as the Internet is borderless, thus obtaining a higher share of foreign sales with relatively limited foreign assets. However, geographically each of these companies is far removed in distance from the key regions that are targeted by the UN 2030 SDGs, especially Africa which has a relatively poor digital infrastructure. Nevertheless, the MNEs and their IP-reliant digital business models are having an impact on sustainable industrialization as discussed further below.

IP rights comprise around $75 \%$ or more of the market value of most enterprises. ${ }^{124}$ High quality IP rights have an important role to play in accelerating the innovation, creativity and 
investment necessary to address major global challenges and improve society. Information and knowledge are fundamental for sustainable and indeed profitable business management. The companies with IP-reliant business models set out in Figure 2 above are exceptional in terms of balance sheet strength, return on capital and high growth. The high level of market capitalization can be largely attributed to highly valuable unrecorded (off balance sheet) intangibles including IPR, as demonstrated by the wide gap between market value. Patents protect the technological hardware and in some cases, such as Amazon's 1 click system, the business method. ${ }^{125}$ The Amazon 1-Click button lets customers buy items with just one click without having to enter and re-enter billing, payment or shipping information. Over the past two decades, the 1-click software innovation became an integral part of Amazon's checkout process. Amazon fiercely protected its 1-Click patent during its period of validity (it expired on 11 September 2017 and is now in the public domain across the globe), suing Barnes \& Noble for implementing a similar technology in the late 1990s. ${ }^{126}$ Amazon also derived a revenue stream from licensing the technology to third parties, such as Apple, Inc. Copyright protects the software and code, narrative content and images on websites. While trademarks protect the brand, and the doctrine of confidential information protects corporate know how and trade secrets. For example, Spotify owns proprietary IP rights and uses digital rights management (DRM) protection. Spotify's contractual terms and conditions for use do not permit users to reverse-engineer the application. ${ }^{127}$ The Swedish company has embraced a mission-driven, flat, and inclusive culture. Value and wealth are created through connections and networks, instead of the management of workers and physical assets. ${ }^{128}$

There is a broad consensus in the business and academic communities that new opportunities will continue to grow through the interconnected processes of globalization and rapid technological change. In particular, the emergence of technologies related to social 
media, platforms and big data which have profoundly disrupted traditional forms of organization and created new business models.

One such opportunity is that IPRs generate more resilient businesses, better quality and higher paid employment. ${ }^{129}$ A joint European Patent Office - EU Intellectual Property Office study highlights the economic benefits for Europe that are derived from IP rights ownership. ${ }^{130}$ The second EU-wide study of the impact of IPRs on the European economy in terms of GDP, employment, wages and trade found that more than $42 \%$ of total economic activity in the EU (some EUR 5.7 trillion annually) is generated by IPR-intensive industries. Further, approximately $38 \%$ of all employment in the EU (82 million jobs) stems from businesses that have a higher than average use of IP rights. The report, which covered a broad range of key IPR, found that average wages in IPR-intensive industries are more than $46 \%$ higher than in other industries. Crucially, IPR intensive industries have played a dramatic role in EU trade, with a very high share of imports (85\%), and an even higher share of exports (93\%), as well as generating a trade surplus of $€ 96.4$ billion for the EU in the period 2011-2013. These businesses also appear to have shown more resilience in the face of the economic crisis, as the study reveals a slight increase in the contribution of these industries to the EU economy since 2010. This is very important data for corporate longevity and ensuring sustainable business and profits. António Campinos, Executive Director of the EUIPO, said:

The rapidly changing nature of business in the 21 st century means that the EU and global economy relies strongly on trademarks, designs, patents and other rights. This poses the challenge of ensuring that IP rights are more accessible to all businesses, and are protected effectively against infringement, in order to help the EU to retain its innovative strengths.

However, the corporate 'stewardship' of the IPRs that protect innovation pervasive in digital business models is not being prioritised to the same extent as is the case with the CSR 
activities of the pharmaceutical companies. According to UNCTAD's Information Economy Report $^{131}$ the transition to a digital economy can provide new tools for tackling the UN's 2030 SGDs. However, a critical challenge for LDCs is the global digital divide, which forms an aspect of SDG Goal 9 industrialization. As the business decisions of the pharmaceutical companies discussed in Figure 1 above directly impact human health in LDCs making CSR efforts particularly important outside Europe and the USA, the CSR activities of the FAANGs and other digital MNEs need to better target innovation to address the digital divide, especially beyond their country of origin. The International Telecommunication Union (ITU) reports three quarters of the population in most developed and emerging economies use the internet and the penetration rate is approaching 50 per cent across developing countries and now exceeds 25 per cent in Africa. ${ }^{132}$ For developing countries, IP-reliant digital business models present immense opportunities for the FAANGs. They can make overseas markets more accessible for exports, including by linking domestic companies and SMEs to GVCs, or create new markets, such as digital applications adapted to specific local conditions. As such, when developing an IP-reliant digital business model, one cannot use exciting new digital services without good, affordable internet connections. Promoting technology and innovation alone is not enough, commercial success is dependent on how the IP-reliant business model works in the market. Digital platforms make new business models for developing-country entrepreneurs and SMEs possible. For example, with support from the World Bank, the Botswana Business Angels Network and the Global Entrepreneurship Network in Botswana brought together local entrepreneurs and global thought leaders to share knowledge and strengthen the operating environment for digital entrepreneurs. ${ }^{133}$ The workshop built upon the recent XL Africa Competition $^{134}$, a pan-African acceleration program to find the 20 most promising digital startups in Africa demonstrating that Africa can produce world-class digital entrepreneurial talent. 
Digital global MNE CSR activities should be encouraged to look beyond national boundaries and adopt a greater focus on the planet's most technologically challenged regions. For example, since 2017 the UK requires large and listed companies to include additional disclosures of non-financial information in their annual reports, similar to the disclosure requirements in the Strategic Report. The Non-Financial Reporting Regulations insert sections 414CA and 414CB into the UK Companies Act 2006, supplementing the existing strategic report requirements as set out in section 414C of the Companies Act 2006. The regulations apply to companies and qualifying partnerships with financial years beginning on or after 1 January 2017. These new requirements potentially increase the reporting of non-financial information, include CSR and 'sustainability' reporting under through the requirement to report the company's business model. This EU-wide reform highlights the growing importance of disclosure of non-financial information. However, presently there is no universal agreement about what constitute good CSR in the context of the UN SDGs, innovation and corporate IP asset ownership. Droppert and Bennett's research explaining the motivations for pharmaceutical companies to engage in CSR also apply to the FAANGs namely: reputational benefits, recruitment and employee satisfaction, better sustainability indices rankings, entrance into new markets and long term economic returns. ${ }^{135}$ To date, business has voluntarily generally accepted CSR for two reasons. First, the reputational brand value risks of ignoring it and second, the potential backlash from increasingly ethical investors who are interested in the UN SDG 2030 Agenda. In terms of transparency and corporate reporting, in 2017 KPMG published its research finding that three-quarters of the 4,900 companies surveyed from around the world published CR reports. ${ }^{136}$ This includes the FAANGs, but they could do more in LDCs and Africa, outside their country of foundation, as is the case with the pharmaceutical firms.

\section{Final discussion, conclusions and recommendations}


Owning IP rights empowers private sector corporations on the business lifecycle from start up to MNE through to the century club. Intangibles and IPRs form a significantly high proportion of corporate value so we need to adjust our sustainability lens to deal with the Third and Fourth Revolutions and the growing magnitude of corporate owned and controlled IP assets. The impact of technological disruptions on the relationship between innovation, IP business models, corporate longevity and sustainability is a new frontier and fresh thinking is needed to formulate and investigate policy responses and action.

\section{Corporate governance, stewardship and the immature digital MNEs}

The corporate and IP concepts of stewardship in business converge to deal initially with creation long-term shareholder value -in such a way that can be sustained into the future - and ethical control of corporate IPRs (section 2). This involves making careful judgements between the immediate self-interest of beneficiaries and the longer term consequences. ${ }^{137}$ Fast-growth technology companies such as the FAANGS examined in Figure 2 above are now central to the new digital and information economy. Their fast growth is due to multiple and interrelated factors, including strong technological innovation and market momentum prompted by the digital revolution, a managerial culture oriented towards investment in $R \& D$ and innovation. Inculcating a higher level of effective stewardships in the FAANGs, their board of directors and investors, with a view to steering clear of irresponsible social and environment risks could assist them to operate more responsibly without destroying shareholder value in the longer term. In return for the legally constructed monopoly corporate and IPR advantages, other countries outside the UK and the Netherlands should be encouraged to adopt a soft law corporate governance stewardship codes to guide corporate decision-making that specifically address sustainability. There is a role for governments and policy makers to further shape the corporate behaviour of digital MNEs through soft and hard corporate and competition law. Within current company law regimes, there is potential for companies to 
reorient themselves towards not just the 'long term' enshrined in s 172 CA 2006 but rather 'sustainability' through the introduction of corporate governance stewardship codes for large and listed company in WTO members states.

\section{Connecting the disciplines to create new theory}

The focus of corporate governance also needs to re-orient to include considerations of innovation theory, UN SDG 2030 Agenda and corporate contribution to CSR sustainability. Research has revealed that strong CSR is positively correlated with corporate longevity. However, young, yet economically powerful digital MNEs are less likely to have strong CSR, especially if they are public companies, as opposed to privately held companies. Those companies have existed and thrived for over a century and some for much longer and are truly sustainable and there is much more that we can learn from them. The author is currently engaged in study to develop a more detailed examination of the characteristics of mature firms in terms of their approach to tradition, stewardship, innovation, profitability, adaptation, social responsibility and sustainability. This data and insights could be instructive to other, younger firms seeking a sustainable pathway in the modern business environment. Such future research may assist to advance the UN's SDG Agenda assist to demonstrate best practice in terms of making a contribution to global sustainability. Firms with new technologies create new markets and value networks that impact on established markets, firms, products and alliances. Firms that act as good stewards and identify, protect and strategically use their IP rights have superior potential for developing sustainable business models developing the resilience necessary to join the century club of sustainable companies. The economic CSR contributions of the MNEs with IP-reliant digital business models discussed in figure 2 above is predicted to grow in alignment with their business life cycle and corporate longevity. As such society should expect a commensurate, publicly reported engagement in CSR activities as a company grows and matures. 
Most importantly, we connected the disciplines and created new theory, namely that for the powerful digital MNE companies to create a long-lasting (sustainable) innovation, they may need to aspire to two things. They must continue to achieve both revolution (disruptive innovation) and sensitive evolution whilst moving steadily toward increased family, employee or other private share ownership (opposed to public ownership) over time, which typically leads to the delivery of a higher level of CSR and sustainability initiatives.

Addressing distrust in IPRs by adjusting existing legal frameworks

While there is an element distrust of the magnitude of corporate IPR ownership embraced by MNEs, the competition law and compulsory licensing legal frameworks already exist but could be upgraded and amended to deal with sustainability and the UN SDG 2030 agenda as discussed in section 4. In particular, fresh thinking resulted in the recommendation that the WTO TRIPS Agreement article 27 be amended to address sustainability as a ground for applying for compulsory IPR licences, as is presently the case in public health emergencies that require urgent access to patent-protected pharmaceuticals. For example, if innovating firms invent new technologies that can help fix and restore the planet, the existing open access patent databases such as Espacenet will capture how the technology works, new patent filings can be monitored and potentially (if TRIPS Article 27 allows) compulsorily licensed. This solution also has the advantage of providing immediate funding for the firm to grow and expand. In summary, it is contended that the compulsory licensing system established under TRIPS needs to embrace not only big pharma, but big tech and sustainability as well to engage stakeholders and garner support for the merits of IP rights.

\section{Assisting FAANGs and digital MNEs to accelerate SDG 9}

Large and public companies across the globe have a key role to play in achieving the UN 2030 SDG Agenda. Harnessing the economic power wielded by the private sector digital MNES into CSR activities outside the USA and Europe and into LDCs and struggling regions 
will contribute to UN2030 SDG 9 and bridge the digital technology divides that exist across the globe. Positive examples of MNE engagement in CSR and sustainability initiatives include such as Virgin and the global pharmaceutical firms in the century club Merck, GSK, Pfizer, Bayer, Eli Lilly and Roche which have been widely recognised as having good practice. Increasing the dialogue between these pharmaceutical MNE firms to share and mentor boards and senior executives of the FAANGS to develop their own CSR and sustainability strategies could prove fruitful. In conclusion, this article has contributed to the sustainability literature by demonstrating how to activate a greater role for the private sector and the FAANGs in innovation, developing new business models, achieving corporate longevity and engaging in CSR tempered by competition law and potentially furthered through compulsory licensing to accelerate the UN 2030 SDG agenda.

\footnotetext{
* Dr Janice Denoncourt (BA McGill, LLB Western Australia, LLM Bournemouth, PhD Nottingham, SFHEA) Senior Lecturer, Nottingham Law School, Nottingham Trent University, UK Janice.denoncourt@ntu.ac.uk ${ }^{1}$ World Population Prospects: The 2015 Revision Report (25 July 2017) UN Department of Economic and Social Affairs, New York, available at http://www.un.org/en/development/desa/news/population/2015report.html

2 J. Vidal 'Nations Urged to Combine Environment and Development Goals' (21 March 2013) The Guardian at https://www.theguardian.com/environment/2013/mar/21/nations-urged-combine-environmental-developmentgoals accessed on 3 August 2018.

${ }^{3}$ B. Rahman, Airini et al. 'Emerging Technologies with Disruptive Effects: A Review' (2017) Perintis eJournal 7 (2)

${ }^{4}$ The shareholder primacy doctrine is a corporate governance theory providing that shareholder interests should be assigned first priority relative to all other corporate stakeholders. A shareholder primacy approach may enable shareholders power to intercede directly and frequently in corporate decision-making. The doctrine of shareholder primacy is criticized for conflicting with corporate social responsibility and other legal obligations because it focuses solely on maximizing shareholder profits. See G. Pearson 'The Truth about Shareholder Primary (25 May 2012) The Guardian available at https://www.theguardian.com/sustainable-business/shorttermism-shareholder-long-term-leadership accessed on 11 April 2019.

${ }^{5}$ United Nations Transforming our World: The 2030 Agenda for Sustainable Development (2015) A/RES/70/1at:

https://sustainabledevelopment.un.org/content/documents/21252030\%20Agenda\%20for\%20Sustainable\%20De velopment $\% 20$ web.pdf

${ }^{6}$ T. Dyllick and K. Muff's article, 'Clarifying the Meaning of Sustainable Business: Introducing a Typology from Business-as-Usual to True Business Sustainability’ (2016) Vol. 29, Issue 2, pp156-174 at https://doi.org/10.1177/1086026615575176 accessed on 17 June 2019.

${ }^{7}$ ISO 26000 Social Responsibility at https://www.iso.org/iso-26000-social-responsibility.html accessed on 17 June.

${ }^{8}$ See 'Innovation' in Merriam-webster.com, Merriam-Webster accessed on 30 August 2018.

${ }^{9}$ S. Maranville, 'Entrepreneurship in the Business Curriculum' (1992) 68 Journal of Education for Business pp27-31, doi: 10.1080/08832323.1992.10117582
} 
${ }^{10}$ P. Frankelius 'Questioning two myths in innovation literature' (2009) 20 The Journal of High Technology

Management Research, pp40-51. doi:10.1016/j.hitech.2009.02.002

${ }^{11}$ Edward Elgar Publishing, ISBN: 978-1-84844-6458

${ }^{12}$ C. Henry and J. Stiglitz, 'Intellectual Property, Dissemination and Sustainable Development' in Global Policy

(4 October 2010), see https:/ doi.org/10.1111/j.1758-5899.2010.0048

${ }^{13}$ Ibid

${ }^{14}$ A.E.L. Brown and C. Waelde, Research Handbook on Intellectual Property and Creative Industries (Research

Handbooks in Intellectual Property Series)_(30 March 2019) Edward Elgar Publishing Ltd

${ }^{15}$ Ibid at $\mathrm{p} 10$.

${ }^{16}$ The Agreement on Trade-Related Aspects of Intellectual Property Rights (TRIPS) is an international agreement administered by the World Trade Organization (WTO) that sets down minimum standards for many forms of intellectual property (IP) regulation as applied to nationals of other WTO Members.

${ }^{17}$ United Nations Department of Economic and Social Affairs, see www.un.org

${ }^{18}$ G.A.M. Ponzetto, 'IPR and Efficient Firm Organization' (May 2014) Barcelona GSE Working Paper Series, Working Paper No 668 at https://pdfs.semanticscholar.org/bf56/a60ba860ec582fabbfd3733151012514ddda.pdf accessed on 11 Janaury 2019

${ }^{19}$ Section 172(1)(a) CA 2006.

${ }^{20}$ D. Million, 'Enlightened Shareholder Value, Social Responsibility, and the Redefinition of Corporate Purpose Without Law' (16 June 2010) Washington \& Lee Legal Studies Paper No. 2010-2011. Enlightened shareholder value (ESV) is the idea that corporations should pursue shareholder wealth with a long-run orientation that seeks sustainable growth and profits based on responsible attention to the full range of relevant stakeholder interests.

${ }^{21}$ V. Tenhaken's original Century Club Company Model comprises five features of corporate longevity: (1) Strong corporate culture (2) long-term business partnerships; (3) active community members; (4) long term employees and (5) unique core strengths. See "A Study of Very Old Japanese Companies: Are There Common Survival Strategies?" with M. Kanda, Global Competitiveness in a Time of Economic Uncertainty and Social Change: Current Issues and Future Expectations (2012).

${ }^{22}$ E.E. Lawler III, 'Corporate Stewardship' (29 September 2015) Huffington Post at https://www.huffingtonpost.com/ed-lawler/corporate-stewardship_b_8215518.html?guccounter=1 accessed on 11 January 2019.

${ }^{23}$ In the English language other terms for steward include ward, guardian or keeper.

${ }^{24} \mathrm{~A}$. Keay 'Stewardship theory: is board accountability necessary?'(2017) Vol. 59 Issue: 6 International Journal of Law and Management, pp.1292-1314 at https://doi.org/10.1108/IJLMA-11-2016-0118 accessed on 11 January 2019.

${ }^{25}$ Davis, J. H., Schoorman, F. D., \& Donaldson, L., 'Toward a stewardship theory of management' (1997).

Academy of Management Review, 22(1), pp20-47

${ }^{26}$ Section 172 Companies Act 2006 (UK)

${ }^{27}$ The Dutch Corporate Code (2018) provides a set of principles for stewardship by assets owners and managers toward Dutch listed investee companies.

${ }^{28}$ Tomorrow's Owners - Defining, Differentiating and Rewarding Stewardship (2009) Tomorrow's Company at https://www.tomorrowscompany.com/ accessed on 20 June 2019. Tomorrow's Company is an independent nonprofit thinkthank that inspires and enables companies to be a force for good in society.

${ }^{29}$ UK financial Reporting Council, The UK Stewardship Code (September 2012), p.1, at:

https://www.frc.org.uk/getattachment/d67933f9-ca38-4233-b603-3d24b2f62c5f/UK-Stewardship-Code-

(September-2012).pdf

${ }^{30}$ Ibid

${ }^{31}$ E.E. Meidenger, 'Laws and Institutions in Cross-Boundary Stewardship' (1998) pp. 87-110 In: Knight, L.

Richard and P. Landres (Editors). Stewardship Across Boundaries. Island Press. ISBN 978-1559635158.

${ }^{32}$ National Academy of Sciences Committee on Ensuring the Utility and Integrity of Research Data in a Digital

Age. 2009. Ensuring the Integrity, Accessibility, and Stewardship of Research Data in the Digital Age. National Academies Press. ISBN 9780309147828.

${ }^{33}$ J. Denoncourt, Intellectual Property, Finance and Corporate Governance (2018) Routledge Taylor Francis

${ }^{34}$ Section 172(1)(a) CA 2006

${ }^{35}$ E. E. Lawler, S. Mohrman and J. O'Toole, Corporate Stewardship: Achieving Sustainable Effectiveness (31 July 2015) Routledge; B. Sjåfjell and B. Richardson (eds.) Company Law and Sustainability - Legal Barriers and Opportunities (2015) Cambridge University Press, ISBN-13: 978-1107043275

${ }^{36}$ R. Huggins and P. Thompson, 'Entrepreneurship, Innovation and Regional Growth: A Network Theory'

(2015) 41(5) Small Business Economics, pp103-128.

${ }^{37}$ P. Azoulay, J.S. Graff Zivin, D. Li and B. Sampat, 'Pubic R\&D Investments and Private Sector Patenting:

Evidence from National Institutes of Health (NIH) Rules (3 Sept 2015) Working Paper 16-056, p.1 
${ }^{38}$ M. Mazzucato and G. Semieniuk, 'Publica financing of innovation: new questions' (2017) Vol 33 No. 1 Oxford Review of Economic Policy, pp.24-48.

${ }^{39}$ World Intellectual Property Indicators (2017) World Intellectual Property Organization, see Patents at pp2940 .

${ }^{40}$ E Subotnik, The Stewardship of Intellectual Property at https://law.depaul.edu/about/centers-andinstitutes/center-for-intellectual-property-law-and-information-technology/programs/ip-scholarsconference/Documents/ipsc 2015/abstracts-papers-presentation/SubotnikE abstract.pdf

${ }^{41}$ H. R Howe 'Property, sustainability and patent law - could the stewardship model facilitate the promotion of green technology?' In H.R. Howe and J. Griffiths eds. Re-shaping intellectual property rights (2012) Cambridge University Press, pp 282-305 at https://doi.org/10.1017/CBO9781107300880.015

${ }^{42}$ Ibid.

${ }^{43}$ H.R. Howe, 'Lockean natural rights and the stewardship model of property' [2013] 3(1) Property Law Review, pp. $36-50$

${ }^{44}$ Supra $\mathrm{n}[3]$

${ }^{45}$ Supra n [15]

${ }^{46}$ E. Schoenherr, 'The Digital Revolution' (5 May 2004) at

https://web.archive.org/web/20081007132355/http:/history.sandiego.edu/gen/recording/digital.html accessed on 11 January 2019

${ }^{47}$ The Word Economic Forum (see www.weform.org) aims to tackles the most significant global challenges through public-private collaboration.

${ }^{48}$ K. Schwab, The Fourth Industrial Revolution (2016) Crown Business, ISBN 978-1-5247-5886-8

${ }^{49}$ Klaus Martin Schwab is a German engineer and economist, best known as the founder and executive chairman of the World Economic Forum. His wife, Hilde, co-founded the Schwab Foundation for Social Entrepreneurship with him. He was born in 1938, in Ravensburg, Germany. Schwab was professor of business policy at the University of Geneva from 1972 to 2002. Since 1979, he has published the annual Global Competitiveness Report which assesses the potential for increasing productivity and economic growth of countries around the world, written by a team of economists. The report is based on Schwab's methodology and on sustainability criteria.

${ }^{50} \mathrm{WIPO}$ is the global forum for IP services, policy, information and cooperation. It is a self-funding agency of the UN with 191 member states (see www.wipo.org). WIPO's mandate, governing bodies and procedures are set out in the WIPO Convention which established WIPO in 1967.

${ }^{51}$ Innovations that meet the legal criteria of patentability may lead to a potentially valuable monopoly right. In the UK, inventions must comply with the requirements set out in the Patents Act 1977 (UK).

${ }^{52}$ A. de Gues, The Living Company: Habits for Survival in a Turbulent Business Environment (2002) Harvard Business Review Press. This book addresses the shift from capitalism to the knowledge society from the perspective of a company as a living being

${ }^{53}$ Ibid.

54 The Standard \& Poor's 500, often abbreviated as the S\&P 500, or j the S\&P, is an American stock market index based on the market capitalizations of 500 large companies having common stock listed on the NYSE or NASDAQ. The S\&P 500 index components and their weightings are determined by S\&P Dow Jones Indices. ${ }^{55} \mathrm{~V}$. Tenhaken, supra $\mathrm{n}[8]$

${ }^{56}$ I. Sasaki, 'How to build a business that lasts more than 200 years - lessons from Japan's shinise companies' (6 June 2019) at accessed on 6 June 2019.

${ }^{57}$ Ibid

${ }^{58}$ Supra n [53]

${ }^{59}$ Ibid, prologue $\mathrm{p} \mathrm{x}$

${ }^{60}$ FAANG is an acronym for the market's five most popular and best-performing technology stocks, namely Facebook, Apple, Amazon, Netflix and Alphabet's Google. FAANG was born out of the original acronym, FANG, which did not include when American TV station CNBC's Jim Cramer coined the term.

${ }^{61}$ United Nations Development Program, Goal 9 Development Industry, Innovation and Infrastructure at http://www.undp.org/content/undp/en/home/sustainable-development-goals/goal-9-industry-innovation-andinfrastructure.html

62 Jiraporn, Pornsit and Withisuphakorn, Pradit, The Effect of Firm Maturity on Corporate Social Responsibility (CSR): Do Older Firms Invest More in CSR? (July 7, 2015). Available at SSRN: https://ssrn.com/abstract=2627951 or http://dx.doi.org/10.2139/ssrn.2627951

${ }^{63}$ Supra n [53]

${ }^{64}$ Supra n [28] p 183.

${ }^{65}$ R. Walsh, 'A history of the pharmaceutical industry' (1 Oct 2010) Pharmaphorum blog at https://pharmaphorum.com/articles accessed on 17 June 2019. 
${ }^{66}$ H. Droppert, S. Bennett 'Corporate Social Responsibility in Global Health: an exploratory study of multinational pharmaceutical firms' (2015) Vol. 11, issue 15, Global Health

${ }^{67}$ Ibid

${ }^{68}$ Supra n [65]

${ }^{69}$ Supra n [49]

${ }^{70}$ V. Tenhaken, 'Family Connection' (20 December 2009) http://howoldcompaniessurvive.blogspot.com/2009/

${ }^{71}$ World Population Prospects: The 2015 Revision Report (25 July 2017) UN Department of Economic and Social Affairs, New York, available at http://www.un.org/en/development/desa/news/population/2015report.html

${ }^{72}$ E. M. Emerson Diffusion of Innovations (2003) $5^{\text {th }}$ ed. Simon and Schuster. ISBN 978-0-7432-5823-4

${ }^{73}$ Ibid, Rogers 1962 edition, p 150

${ }^{74}$ C. M. Christensen, Michael Raynor and Rory McDonald. 'What is Disruptive Innovation?' Harvard Business Review (December 2015) Vol. 93 No. 12, pp. 44-53. Professor Christensen is the Kim B. Clark Professor of Business Administration at the Harvard Business School; and is a leading expert on innovation and business growth.

${ }^{75}$ Airbnb, Inc. is a privately-held global company headquartered in San Francisco, US that operates an online marketplace and hospitality service which is accessible via its websites and mobile apps. Members can use the service to arrange or offer lodging, primarily homestays, or tourism experiences. It was founded by CEO Brian Chesky in August 2008 and has a revenue of 2.6Billion USD (2017) as well as subsidiaries, Tilt.com and Trooly, Inc.

${ }^{76}$ Uber Technologies Inc. is a peer-to-peer ridesharing, taxi cab, food delivery, bicycle-sharing, and transportation network company headquartered in San Francisco, California, with operations in 785 metropolitan areas worldwide. Its platforms can be accessed via its websites and mobile apps. It was founded by Travis Kalanic and Garret Camp in March 2009 in San Francisco, US and has a revnuew of 6.5billion USD (2016) as well as subsidiaries, Uber Eats, Jump Bikes, Otto, Rasier LLC, deCarata, and MORE.

${ }^{77}$ Supra [n56]

${ }^{78}$ Adapted from Deloitte Israel https://www2.deloitte.com/il/en/pages/innovation/article/disruptive_vs_sustaining.html

${ }^{79}$ Summarised from the entry for Sir Richard Branson in www.ukwhoswho.com. (2014) A\& C Black (Ed.)

Oxford University Press and Bloomsbury Publishing plc

${ }^{80}$ See www.vireginearth.com

${ }^{81}$ D. French and L. Kotze, Sustainable Development Goals: Law, Theory and Implementation (2018) Edward Elgar, ISBN 1286438755.

82 The World Trade Organization (WTO) and World Intellectual Property Organization (WIPO)

${ }^{83}$ The free-rider problem refers to a market failure that occurs when people use another's proprietary IP without paying for it or without the owner's permission and may amount to an IP rights infringement.

${ }^{84}$ OECD Policy Roundtable: Competition Policy and Intellectual Property Rights (1997) See http://www.oecd.org/competition/abuse/1920398.pdf accessed on 1 November 2018.

${ }^{85} \mathrm{Ibid}$

${ }^{86}$ W. Baumol, Welfare Economics and the Theory of the State (1952) Harvard University Press, Cambridge, Massachusetts

${ }^{87}$ Navigating the SDGs: A business guide to engaging with UK Global Goals (2016) PWC at https://www.pwc.com/gx/en/sustainability/publications/PwC-sdg-guide.pdf accessed on 11 January 2019.

${ }^{88} \mathrm{~J}$. Haskel and S. Westlake, Capitalism without Capital (2017) Princeton University Press, 2018 Haskel is professor of economics at Imperial College Business School. Westlake is advisor to the UK Minister of Science and Innovation. They were co-winners of the 2017 Indigo Prize.

${ }^{89}$ Supra C. Christiansen [n56]

${ }^{90}$ Section 25(1) PA 1997

${ }^{91}$ J. Phillips, 'The English Patent as a Reward for Invention: The Importance of an Idea'(1982) 3 Journal of Legal History 71

${ }^{92} \mathrm{~F}$. Munari, and R. Oriani (2011) p $x i$

${ }^{93}$ Section 60 PA 1977

${ }^{94}$ Section 14 PA 1977

${ }^{95}$ B.Hall, C. Helmers, M. Rogers, and S. Vania. 'The importance (or not) of patents to UK firms' p1 at: http://niesr.ac.uk/sites/default/files/publications/dp410.pdf

${ }^{96}$ Ibid $\mathrm{p} 4$

${ }^{97}$ Supra Hall [47] p10

${ }^{98}$ The key disadvantage of a trade secret is its vulnerability to reverse engineering. 
99 The act of publishing a detailed description of a new invention (without patenting it) to disclose prior art and public identification as the originator, or anonymously. A defensive publication prevents others from later being able to patent the invention.

${ }^{100}$ B. H. Hall, 'Is there a role for patents in the financial of innovative firms?' (26 July 2018) Oxford Business

Law Blog, at https://www.law.ox.ac.uk/business-law-blog/blog/2018/07/there-role-patents-financing-newinnovative-firms accessed on 26 July 2018.

101 Ibid.

102 Supra OECD [46]

${ }^{103}$ See M. Boldrin Against Intellectual Monopoly (4 Mar $20101^{\text {st }}$ ed.) Cambridge University Press; J. Axhamnm 'Copyright in a Borderless Online Environment' (1 June 2012) Stockholm University, at http://copyrightblog.kluweriplaw.com/2012/06/01/copyright-in-a-borderless-online-environment/ accessed on 17 June 2019.

${ }^{104}$ M. Boldrin, and D.K. Levine, 'The Case Against Intellectual Property’ (March 2002) CEPR Discussion Paper No. 3273 at SSRN: https://ssrn.com/abstract=307859 accessed on 18 June 2019.

${ }^{105}$ In general, all WTO members must provide patent protection (Article 27.1 TRIPS) which has to last for 20 years form the date the patent application was filed (Article 33 TRIPS). Members cannot discriminate between different fields of technology, or place of invention or whether products are imported or locally produced (Art 27.1) WTO Facts Sheet: TRIPS and Pharmaceutical Patents at https://www.wto.org/english/tratop_e/trips_e/factsheet_pharm02_e.htm accessed on 17 June 2019.

${ }^{106}$ Section 60 UK Competition Act 1998 provides that UK rules are to be applied in line with European jurisprudence and as with all competition law prohibiting practices that restrict free trade and competition between business entities and banning abusive behaviour by a firm dominating a market, or anti-competitive practices that tend to lead to such a dominant position. Practices controlled in this way may include predatory pricing, tying, price gouging, refusal to deal etc. The UK's Competition and Markets Authority enforces competition law on behalf of the public.

107 T. Wu, The Curse of Bigness: Antitrust in the New Gilded Age (13 November 2018) Columbia Global Reports (13 Nov. 2018)

108 Ibid.

${ }^{109}$ Supra $\mathrm{n}[91]$.

${ }^{110}$ A. Rassweiller, M.C. Boyadjis and S Brinley, 'Tesla Motors: A case study in disruptive innovation' HIS Market available at https://ihsmarkit.com/research-analysis/q14-tesla-motors-a-case-study-in-disruptiveinnovation.html accessed on 11 January 2019.

${ }^{111}$ S. Brachmann, 'Apple continues building dominant mobile patent portfolio' (29 January 2015) at http://www.ipwatchdog.com/2015/01/29/apple-continues-building-dominant-mobile-patent-portfolio/id=54070/ ${ }^{112}$ Ibid

${ }^{113}$ H. Chesborough, Open Innovation: Research a New Paradigm (15 April 2008) Oxford University Press.

114 UNCTAD Chapter IV Investment in the Digital Economy accessed on 28 September 2018 at http://unctad.org/en/PublicationChapters/wir2017ch4_en.pdf

${ }^{115}$ Forbes Global 2000: World's Largest Public Companies (June 2018) edited by H. Tourvalai and K. Stoller with data by Andrea Murphy at https://www.forbes.com/global2000/?utm_source=FBPAGE\&utm medium=social\&utm_content=1576818626 \&utm_campaign=sprinklrForbesMainFB\#44be79f3335d accessed on 13 June 2018. The methodology for compiling the rankings relies on data from FactSet Research systems to screen for the biggest public companies in four metrics: sales, profits, assets and market value.

116 J. Bonamazzo 'Uber's SEC-Approved Business Model' (25 October 2017) The Observer at https://observer.com/2017/10/uber-going-public-sec-business-model-driver-earnings/

${ }^{117}$ How Airbnb Works | Insights into Business \& Revenue Model accessed on 28.10.2018 at https://jungleworks.com/airbnb-business-model-revenue-insights/

118 The Difference Between Amazon And Alibaba's Business Models (2 August 2016) Investopia accessed on 28 September 2018 at https://www.investopedia.com/articles/investing/061215/difference-between-amazonand-alibabas-business-models.asp

119 This is extra-ordinary, by way of comparison traditional old companies have a PE ratio of 12 . This is more 'normal'.

${ }^{120}$ Supra n [59]

121 J. Montgomerie and S. Roscoe, 'Owning the consumer-Getting to the core of the Apple business model' (December 2013) Vol. 37, Issue 4 Accounting Forum, pp 290-299

122 Reliable IP statistics are an important tool in understanding trends in policy, business, and technology worldwide. WIPO cooperates with national IP office around the world to provide the most up-to-date global IP data. WIPO's IP Facts and Figures 2017 (2018) publication gives an overview.

${ }^{123}$ Supra n [56] 
${ }^{124}$ In the UK, intangible assets are now estimated to represent $70-80 \%$ of the value of UK companies UKIPO [insert reference]

${ }^{125}$ S. Pathak, 'End of an Era: Amazon's 1-click Buying Patent Finally Expires' (12 September 2017) available at: https://digiday.com/marketing/end-era-amazons-one-click-buying-patent-finally-expires/

${ }^{126}$ R. Pol Wagner and T. Jeitschko, 'Why Amaon's '1-Click' Ordering was a Game Changer (14 September 2017 at http://knowledge.wharton.upenn.edu/article/amazons-1-click-goes-off-patent/ accessed on 11 January 2019

${ }^{127}$ Terms and Conditions of Use: User Guidelines (1 November 2016) Spotify at https://www.spotify.com/caen/legal/end-user-agreement/\#s8 accessed 13 June 2018.

${ }^{128}$ I. Noterman, 'Spotify Inclusion Summit 2018 (5 May 2018) Spotify HR Blog at https://hrblog.spotify.com/2018/05/04/spotify-inclusion-summit-2018/ accessed on 11 January 2019.

${ }^{129}$ Supra n[11]. Note that Searle found little evidence of IP rights significantly impacting the structure of business models in the creative industries; instead it is seen as a 'secondary influence'. However, within the various branches of the creative and cultural industries, different strategies of value appropriation have evolved, accompanied by conflicting views as to if, and how, to renew copyright-related business models.

${ }^{130}$ Joint EPO-EUIPO study highlights economic benefits of IP for Europe (25 October 2016) European Patent Office available at https://www.epo.org/news-issues/news/2016/20161025.html

${ }^{131}$ UNCTAD, 2015a

${ }^{132}$ Facts and Figures ITS 2017 Report (2017) ITU available at https://www.itu.int/en/itu-

D/Statistics/Documents/facts/ICTFactsFigures2017.pdf accessed on 11 January 2019

${ }^{133}$ World Bank Supports Young Digital Entrepreneurs in Botswana (21 February 2018) World Bank accessed on 28 September 2018 at https://www.worldbank.org/en/news/press-release/2018/02/21/world-bank-supportsyoung-digital-entrepreneurs-in-botswana

${ }^{134}$ XL Africa Accelerating Africa's Digital Start Ups (18 December 2017) at http://www.worldbank.org/en/news/feature/2017/12/18/xl-africa-accelerating-africas-growth-oriented-start-ups ${ }^{135}$ Supra $\mathrm{n}[66]$

${ }^{136}$ The road ahead: The KPMG Survey of Corporate Responsibility Reporting (2017) KPMG, available at https://assets.kpmg/content/dam/kpmg/xx/pdf/2017/10/kpmg-survey-of-corporate-responsibility-reporting2017.pdf accessed on 11 January 2019

${ }^{137}$ Supra $\mathrm{n}[28]$ 